\title{
Effect of Fly Ash and Nitrogen on Growth and Productivity of Bt Cotton (Gossypium hirsutum L.)
}

\author{
Hardial Singh and Balwinder Singh Dhillon* \\ College of Agriculture, Guru Kashi University, Talwandi Sabo, Punjab, India \\ *Corresponding author
}

\begin{tabular}{l} 
Ke y w o r d s \\
$\begin{array}{l}\text { Cotton, Fly ash, } \\
\text { Growth, Nitrogen, } \\
\text { Yield }\end{array}$ \\
Article Info \\
$\begin{array}{l}\text { Accepted: } \\
10 \text { November } 2020 \\
\text { Available Online: } \\
10 \text { December } 2020\end{array}$ \\
\hline
\end{tabular}

Keywords

Cotton, Fly ash, Growth, Nitrogen, Yield

Article Info

Accepted:

Available Online:

10 December 2020

\section{A B S T R A C T}

A field experiment entitled "Effect of fly ash and nitrogen on the growth and yield of Bt cotton (Gossypium hirustum L.)" was conducted during the kharif season of 2018 at Research Farm of Guru Kashi University, Talwandi Sabo, Bathinda (Punjab). The soil of the experimental field was loamy sand, low in organic carbon and available nitrogen, medium in available potassium and phosphorus. The trail was laid out in split plot design with two levels of fly ash viz. 0 and $10 \mathrm{t} \mathrm{ha}^{-1}$ in main plots and four levels of Nitrogen $\left(0,125,150\right.$ and $\left.175 \mathrm{~kg} \mathrm{ha}^{-1}\right)$ in sub plots. The results showed that the fly ash $10 \mathrm{tha}^{-1}$ gave significantly higher growth and yield attributes over control. Application of nitrogen $175 \mathrm{~kg} \mathrm{ha}^{-1}$ gave significantly higher plant height, dry matter accumulation, leaf area index, number of sympodial branches per plant, number of bolls per plant, boll weight, seed cotton yield ,stalk yield and biological yield as compared to $0,125,150 \mathrm{~kg} \mathrm{~N} \mathrm{ha}^{-1}$. The results showed that application of nitrogen $175 \mathrm{~kg} \mathrm{~N} \mathrm{ha}^{-1}$ gave significantly higher seed cotton yield $(104,23.8,3.9 \%)$ over $0,125,150 \mathrm{~kg} \mathrm{~N} \mathrm{ha}^{-1}$ respectively. On the basis of present investigation, it can be concluded that $175 \mathrm{~kg} \mathrm{~N} \mathrm{ha}^{-1}$ gave higher growth and yield attributes but at par with the application of $150 \mathrm{~kg} \mathrm{~N} \mathrm{ha}^{-1}$.

\section{Introduction}

American cotton (Gossypium hirustum L.) also known as "upland cotton" originated in South America, is most widely cultivated fibre crop of the world and contributes abbot 95\% of the approximately 110 Million bales of cotton produced throughout the world. It is an important cash crop known as white gold and is also known as the king of fibre crops.
Major cotton growing countries are USA, Russia, India, Brazil, Mexico and Sudan. India ranks first in the world with respect to area under cultivation. This being the important cash crop of the country benefits several million people by providing employment opportunities i.e. cultivation, trade, manufacturing, processing. It is not a source of fiber only, but also a good source of edible oil, which play an important role to 
meet the demand of ever increasing population of India. Besides this, this crop also provides fuel for different purposes. Four species of the genus gossypium viz. hirustum, barbadense, arboreum and harbaceum are cultivated, hirustum occupies the first place.

Major cotton growing states in the country are Maharashtra, Gujarat, Karnataka, Madhya Pradesh, Punjab, Rajasthan, TamilNadu and Uttar Pradesh. Maharashtra is the largest producer and is followed by Gujarat. In Punjab, Bt Cotton (Gossypium hirustum L.) and gossypium arboreum L.) are cultivated, however, the area under the cotton is decreasing. During the year 2017-18 cotton was grown on area of 2.87 lakh ha with production of 12.71 lakh bales. Whereas desi cotton (Gossypium arboreum L.) was cultivated on an area of 4 thousand ha with the production of 12 thousands bales. Desi cotton relatively lower yielding species then the Bt cotton (hirsutum). The present study was, therefore, undertaken on Bt cotton.

Nitrogen is the key limiting nutrient for cotton production under irrigated conditions. Nitrogen management practices under cotton cultivation in India are highly inefficient but can be substantially improved through better fertilizer management (Kienzler, 2010). This is because of the fact that the cotton performance is greatly influenced by slight change in the prevailing environment like rainfall, fertility etc. The nitrogen fertilization has contributed greatly to cotton production, because it plays a vital role in cotton growth and yield (Chaudhry, 2007). Among the many strategies to improve the cotton productivity, split application of fertilizers especially nitrogen has proven more productive and profitable (Mahmood-ul-Hasan et al., 2003).

The mineralogical, physical and chemical properties of fly ash depend on the nature of the parent coal, condition of the combustion, type of emission control devices and storage and handling methods. Formation of fly ash depends on the ash content of coal and Indian coal used in power plants generally has very high ash content (30-45\%) and is of lower quality (Mathur et al., 2003). Presence of essential plant nutrients such as $\mathrm{N}, \mathrm{P}, \mathrm{K}, \mathrm{Ca}$, $\mathrm{Mg}, \mathrm{S}$ and micronutrients make it a source of plant nutrients and increase the yield of several crops by $20-25 \%$ and found beneficial for soil and crop when it was applied in optimum quantity (Kohli et al., 2010). Addition of fly ash improved the workability of the soil. The effect of the addition of fly ash is to significantly improve the physical properties of the black cotton soil. Fly ash contains oxides, hydroxides, carbonates, silicates and sulfates of calcium, iron, aluminium and other metal, in trace amount.

\section{Materials and Methods}

The present investigation entitled "Effect of different fly ash and nitrogen levels on the growth and yield attributes of Bt cotton" carried out in experimental area of agriculture research farm of Guru Kashi University, Talwandi Sabo (Bathinda) during kharif 2018-19. The soil of the experimental field was loamy sand, low in organic carbon and available nitrogen, medium in available potassium and phosphorus. The trail was laid out in split plot design with two levels of fly ash viz. 0 and $10 \mathrm{t} \mathrm{ha}^{-1}$ in main plots and four levels of Nitrogen $\left(0,125,150\right.$ and $\left.175 \mathrm{~kg} \mathrm{ha}^{-1}\right)$ in sub plots. Proper field preparation was done in the experimental field. Application of nitrogen according to the treatment but other nutrient, weed management, plant protection applied as per the recommended package of practice. The observations were on plant height at maturity, dry matter accumulation, leaf area index, number of sympodial branches/plant, number of bolls/plant, boll weight, seed cotton yield, stalk yield, biological yield and harvest index. 
Fisher's ANOVA technique and least significant difference (LSD) test at 5\% probability level was used to compare differences among treatment means (Steel et al., 1997).

\section{Results and Discussion}

\section{Growth parameters}

Application of fly ash had influence on plant height, dry matter accumulation, leaf area index (Table 1). Application of fly ash $10 \mathrm{t}$ $\mathrm{ha}^{-1}$ recorded higher plant height $(208.2 \mathrm{~cm})$, dry matter accumulation (25.86q/ha) and leaf area index (2.26) over the control. The data related to dry matter accumulation was in agreement with Matte and Kene (1995). Application of fly ash found to be nonsignificant on plant height. Among the nitrogen levels $175 \mathrm{~kg} \mathrm{~N} \mathrm{ha}{ }^{-1}$ significantly influence the plant height, dry matter accumulation, leaf area index (Table 1). Application of $175 \mathrm{~kg} \mathrm{~N} \mathrm{ha}{ }^{-1}$ recorded significantly higher plant height $(217.9 \mathrm{~cm})$, dry matter accumulation (29.45q/ha), leaf area index (2.33). The present results on growth parameters were also agreed with Nehra and Kumawat (2007), Sagarka et al., (2002) and Chimanshette et al., (1990) respectively.

\section{Yield attributing characteristics}

The yield components namely number of sympodial branches/plant, number of bolls/plant, boll weight shows significant variation with application of fly ash $10 \mathrm{tha}^{-1}$ (Table 2). Application of fly ash 10t ha ${ }^{-1}$ recorded higher number of sympodial branches/plant (29.3), number of bolls/plant (53.6), boll weight (4.94g). Data related to boll weight shows non-significant effect with application of fly ash. Among the nitrogen levels $175 \mathrm{~kg} \mathrm{~N} \mathrm{ha}{ }^{-1}$ significantly influence number of sympodial branches/plant, number of bolls/plant, boll weight, seed cotton yield (Table 2). With application of $175 \mathrm{~kg} \mathrm{~N}^{-1}$ recorded significantly higher number of sympodial branches/plant (31.9), number of bolls/plant (55.4) and boll weight (5.06g) as compared to other nitrogen levels. The present study was in agreement with Nehra and Kumawat (2003), Bhaskar et al., (1993) and Devi et al., (1995) respectively.

Table.1 Effect of different fly ash and nitrogen levels on growth parameters of Bt cotton

\begin{tabular}{|c|c|c|c|}
\hline Fly ash levels (t/ha) & $\begin{array}{c}\text { Plant height } \\
(\mathbf{c m})\end{array}$ & $\begin{array}{c}\text { Dry matter } \\
\text { accumulation } \\
(\mathbf{q} / \mathbf{h a})\end{array}$ & Leaf area index \\
\hline Control & 190.4 & 23.26 & 2.14 \\
\hline $\mathbf{1 0}$ & 208.2 & 25.86 & 2.26 \\
\hline LSD (0.05\%) & NS & 1.80 & 0.03 \\
\hline Nitrogen levels (kg/ha) & & & 2.08 \\
\hline $\mathbf{0}$ & 178.9 & 18.43 & 2.16 \\
\hline $\mathbf{1 2 5}$ & 195.9 & 23.43 & 2.24 \\
\hline $\mathbf{1 5 0}$ & 205.6 & 26.96 & 2.33 \\
\hline $\mathbf{1 7 5}$ & 217.9 & 29.45 & 0.05 \\
\hline LSD (0.05\%) & 13.7 & 1.95 & \\
\hline
\end{tabular}


Table.2 Effect of different fly ash and nitrogen levels on yield parameters of Bt cotton

\begin{tabular}{|c|c|c|c|}
\hline Fly ash levels (t/ha) & $\begin{array}{c}\text { Number of } \\
\text { sympodial } \\
\text { branches/plant }\end{array}$ & $\begin{array}{c}\text { Number of } \\
\text { bolls/plant }\end{array}$ & Boll weight (g) \\
\hline Control & 26.0 & 44.6 & \\
\hline $\mathbf{1 0}$ & 29.3 & 53.6 & 4.78 \\
\hline LSD (0.05\%) & 1.2 & 2.0 & NS \\
\hline Nitrogen levels (kg/ha) & & & 4.65 \\
\hline $\mathbf{0}$ & 22.1 & 41.1 & 4.81 \\
\hline $\mathbf{1 2 5}$ & 27.8 & 47.7 & 4.93 \\
\hline $\mathbf{1 5 0}$ & 28.7 & 52.1 & 5.06 \\
\hline $\mathbf{1 7 5}$ & 31.9 & 55.4 & 0.04 \\
\hline
\end{tabular}

Table.3 Effect of different fly ash and nitrogen levels on productivity of Bt cotton

\begin{tabular}{|c|c|c|c|c|}
\hline $\begin{array}{c}\text { Fly ash levels } \\
\text { (t/ha) }\end{array}$ & $\begin{array}{c}\text { Seed cotton } \\
\text { yield (q/ha) }\end{array}$ & $\begin{array}{c}\text { Stalk yield } \\
(\mathbf{q} / \mathbf{h a})\end{array}$ & $\begin{array}{c}\text { Biological yield } \\
(\mathbf{q} / \mathbf{h a})\end{array}$ & $\begin{array}{c}\text { Harvest index } \\
(\mathbf{\%})\end{array}$ \\
\hline Control & 15.97 & 22.83 & 38.72 & 40.4 \\
\hline $\mathbf{1 0}$ t/ha & 16.98 & 25.00 & 41.90 & 39.8 \\
\hline LSD (0.05\%) & 0.51 & 1.74 & 2.14 & \\
\hline $\begin{array}{c}\text { Nitrogen levels } \\
\text { (kg/ha) }\end{array}$ & & & & \\
\hline $\mathbf{0}$ & 9.86 & 17.62 & 27.48 & 35.8 \\
\hline $\mathbf{1 2 5}$ & 16.25 & 23.98 & 39.74 & 40.8 \\
\hline $\mathbf{1 5 0}$ & 19.36 & 25.98 & 45.34 & 42.6 \\
\hline $\mathbf{1 7 5}$ & 20.12 & 28.57 & 48.69 & 41.3 \\
\hline LSD (0.05\%) & 1.26 & 1.91 & 3.29 & $\mathrm{NS}$ \\
\hline
\end{tabular}

\section{Productivity}

Application of fly ash had influence on productivity of $\mathrm{Bt}$ cotton. With application of fly ash $10 \mathrm{t} \mathrm{ha}^{-1}$ significantly influence the seed cotton yield $(16.98 \mathrm{q} / \mathrm{ha})$, stalk yield $(25.00 \mathrm{q} / \mathrm{ha})$ and biological yield $(41.90 \mathrm{q} / \mathrm{ha})$ (Table 3). Harvest index found to be nonsignificant with application of fly ash. Data related to seed cotton yield and stalk yield with application of fly ash was in agreement with Saini et al., (2010). Among the nitrogen levels $175 \mathrm{~kg} \mathrm{~N} \mathrm{ha}^{-1}$ recorded maximum seed cotton yield (20.12q/ha), stalk yield (28.57q/ha) and biological yield (48.69q/ha) as compared to other nitrogen levels (Table 3 ). Data related to stalk yield with application of nitrogen was in agreement with Siag and Verma (1994).

From the above findings, it can be concluded that the application of fly ash recorded significantly higher growth and yield parameters (dry matter accumulation, leaf area index, number of sympodial branches, number of bolls, seed cotton yield, stalk yield 
and biological yield). Among the different nitrogen levels, application of $175 \mathrm{~kg} \mathrm{~N} / \mathrm{ha}$ recorded the higher growth parameters, yield attributes and seed cotton yield than the lower levels of nitrogen.

\section{References}

Bhaskar, K S, Gaikwad, S T and Kumari, P A (1993). Response of upland cotton (Gossypium hirustum) to the levels of fertilizers in shallow soils of Saongi watershed near Nagpur. Indian Journal of Agronomy. 38(1) 89-92.

Chaudhary R (2007). Update on cost of producing cotton in world. International Cotton Advisory Committee.

Chimanshette, T G, Shelke, V B, Hudge, V S and Hasanbade, A R (1990). Dry matter production and leaf area index as influenced by fertilizer and nitrogen levels in cotton. Annals of Plant Physiology 4(2): 198-204.

Devi, C M Reddy B R, Reddy, P M and Reddy S C S(1995). Effect of N levels and plant density on yield and quality of JKHY-1 cotton. Current Agriculture Research. 8(3-4): 144-46.

Kienzler K. (2010). Improving the nitrogen use efficiency and crop quality in the Khorezm region, Uzbekistan Dissertation, ZFF/ Rheinische FtiedrichWilhelms-University Bonn.

Kohali, S J and Goyal, D (2010). Effect of fly ash application on soil physical properties and microbial activities of soil. Acta Agrophysical 16(22), 327-35. Mahmood-ul-Hasan; Taj Muhammad and
Muhammad Nasrullah. (2003). Cotton response to split application of nitrogen fertilizer. Asian Journal of Plant Science 2(6): 457-60.

Matte, D B and Kene, D R (1995). Effect of fly ash application on yield performance of kharif and rabi crops. Journal of Soils and Crops, 5(2): 133-36.

Nehra P L, Kumawat P D (2003). Response of hirustum cotton verities to spacing and nitrogen levels. Journal of cotton Research and Development 17(1): 41'42.

Nehra P L, Kumawat P D and Nehra K C (2003). Response of promising (Gossypium hirustum L.) hybrid to fertilizer levels in irrigated north western plain zone of Rajsthan. Indian Journal of Cotton Research and Development 20(1):87-88.

Sagarka B S, Malavia D D Solan R M Kachot N A and Dabhi B M (2002). Effect of irrigation method and nitrogen on yield and quality of winter cotton (Gossypium hirustum. L) Indian Journal of Agronomy 47(4): 544-49.

Saini, S P, Manchanda, J S, Kansal, B D and Arora, C L (2010). Effect of fly ash and FYM application on yield and macro and micronutrients availability to rice. Environmental Economics. 28(2): 92329.

Siag, R K and Verma, B L (1994). Dry matter and nutrient uptake by cotton under different irrigation schedules, nitrogen levels and plant density. Journal of Cotton Research and Development. 8(1): 32-40.

\section{How to cite this article:}

Hardial Singh and Balwinder Singh Dhillon. 2020. Effect of Fly Ash and Nitrogen on Growth and Productivity of Bt Cotton (Gossypium hirsutum L.). Int.J.Curr.Microbiol.App.Sci. 9(12): 946-950. doi: https://doi.org/10.20546/ijcmas.2020.912.114 